of the Geological Survey, Dr. Taylor continued lecturing work at the Working Men's College, Crowndale Road, London, and has been a member of Council of that College for many years. It will be clear from these varied activities that Dr. Taylor is a man of personality and drive. He has had a wide experience in geological work in the class-room and in the field in Britain, America and on the Continent, and will bring a highly trained, versatile and well-balanced mind to the problems of university education in geology.

Engineering at the University of Leeds:

Prgf. D. G. Christopherson, O.B.E.

Dr. D. G. WHRI Hormarson, whose appointment as profe or of nanical engineering at the Univer. sity of legds, $n$ succession to the late Prof. W. T. David, has an announced, was educated at Sherbope Schoor and University College, Oxford, where he foul tirst-class honours in engineering science in 193f. He held a Henry Fellowship at Harvard University during 1938-39, and was for several years a member of Sir Richard Southwell's research team developing 'relaxation methods'. He was part author of the first paper in which the application of these methods to partial differential equations was presentéd, and his thesis for the Ph.D. degree in 1941 dealt entirely with this important branch of the work. During the period 194l-45, he was a member of the scientific staff of the Research and Experiments Department, Ministry of Home Security, and was made an O.B.E. in 1945. Dr. Christopherson was appointed a University demonstrator in the Department of Engineering, Cambridge, in April 1945, and was elected a Fellow of Magdalene College. In 1946 he was promoted to lecturer and in 1947 he became bursar of Magdalene. Though Christopherson has con. tributed papers on vibrations and structural problems, his interests lie mainly in the region of applied mechanics, and particularly in the theory of lubrication.

Holweck Prize and Medal : Prof. L. F. Bates

Dr. L. F. BATES, Lancashire-Spencer professor of physics in the University of Nottingham, has been awarded tho/Holweck Prize and Medal by the Société Française/de Physique. The Holweck Prize was founded by the Physical Society as a memorial to Fernand Holweck, director of the Curie Laboratory of the Radium Institute in Paris, and to other French physicists who were killed by the Germans during the occupation. The Société Française de Physique founded the Holweck Medal in bronze for presenta. tion to the prizewinner. The award is made annually, alternately to a French and to a British physicist, for distinguished work in experimental physics. Prof. Bates is a leading authority on experimental magnetism. His book "Modern Magnetism", which appeared in 1939, has achieved an international reputation, and a second revised and enlarged edition appeared last year. His original work in an experimental field known for its difficulty is distinguished by a technique which he has built up since 1924 entirely by independent effort. In particular, his work on the heat liberated in step-by-step magnetism in the hysteresis cycle has advanced knowledge in a field where progress has long been retarded by the experimental difficulties. His work on the changes of specific heat at the ferromagnetic Curie point and his investigations of other properties of ferromagnetic substances are outstanding. His investigations in magnetism constitute a solid body of successful achievement which commands attention and admiration both at home and abroad. Magnetism is a subject in which there is now much interest in France, as instanced by the work of Néel and his school, and Prof. Bates will be warmly welcomed when he delivers his lecture in Paris in the early summer.

\section{University of Birmingham and the Midland Region}

Among other tqpics dealt with by the ViceChancellor of the friversity of Birmingham (Sir Raymond Pliest $2 y$ in his report to the Court of Governors is that of the cordial relations between the University and the Midland region. During the period 1935-47 the University received $£ 1,450,000$ in bapefactons, excluding further promises under sevenye. covenants of about $£ 700,000$, a fine record for its friends and supporters; and in this respect it surpasses all universities except Oxford. Local govern. ment grants, too, have substantially increased, facts which are regarded by the Vice-Chancellor as a recognition of success and a token of confidence. A significant development has been the establishment of the Midland Advisory Council on Industrial Productivity, "an attempt to gear the new develop. ment in Engineering Production (made possible by the generous benefaction of Messrs. Joseph Lucas, Ltd.) to the regional productive drive". The Lucas chair in the principles of engineering production, of which Prof. T. U. Matthew is the first occupant, has as its object postgraduate teaching and research on engineering production and the principles of industrial management. This Advisory Council is intended to promote eloser liaison between Midland industries and the University of Birmingham in order to improve standards of productivity. A further expression of the support of industry is the generous provision by Tube Investments, Ltd., of $£ 1,500$ per annum for seven years for the establishment of a research fellowship in engineering production. The first holder of this fellowship is Mr. Mansergh Shaw, senior lecturer in engineering in the University of Melbourne. To assist Prof. Matthew in developing the postgraduate courses, Mr. P. B. R. Gibson has been appointed as lecturer, and lectures in engineering economics for final-year mechanical and electrical engineering students have been arranged as introductory to the postgraduate courses. It is expected that postgraduate students will be, in the main, sent by industrial firms; they will be expected to have had considerable industrial experience and to possess the attributes essential for success in management.

\section{Philosophical Society of the Sudan}

A NATION is judged not only by its resources and productivity but also by its standard of scholarship and culturg; and an indication of this may be estimated/by its number and quality of learned societieg. In company with the present-day awakening throughout Africa, the Sudan is, and has been, maly.ng great progress in the field of economic defelopment and towards a larger measure of selfgovernment. It is pleasant to report that learning is keeping pace with this development, and that the Philosophical Society of the Sudan, which was founded on February 2, 1946, is flourishing and setting a high standard. The Proceedings for 1946-47 record the activities of this Society for the first year of its existence. At the inaugural meeting seventyfive founder members were enrolled, and the officers and committee were elected. Soon after, at the first ordinary meeting, the president, Mr. A. J. Arkell, gave his address. After discoursing on archæological 